ISLAM AND POPULAR CULTURE 
THIS PAGE INTENTIONALLY LEFT BLANK 


\section{ISLAM AND POPULAR CULTURE}

EDITED BY KARIN VAN NIEUWKERK, MARK LEVINE, AND MARTIN STOKES 
Copyright (C) 2016 by the University of Texas Press

All rights reserved

Printed in the United States of America

First edition, 2016

Requests for permission to reproduce material from this work should be sent to: Permissions

University of Texas Press

P.O. Box 7819

Austin, TX 78713-7819

http://utpress.utexas.edu/index.php/rp-form

(a) The paper used in this book meets the minimum requirements of ANSI/NISO Z39.48-I992 (RI997) (Permanence of Paper).

LIBRARY OF CONGRESS CATALOGING-IN-PUBLICATION DATA

Islam and popular culture / edited by Karin van Nieuwkerk, Mark LeVine, and Martin Stokes. - First edition.

pages $\mathrm{cm}$

Includes bibliographical references and index.

ISBN 978-I-4773-0887-5 (cloth : alk. paper)

ISBN 978-I-4773-0904-9 (pbk. : alk. paper)

ISBN 978-I-4773-0888-2 (library e-book)

ISBN 978-I-4773-0889-9 (non-library e-book)

I. Islam and culture - Islamic countries-2oth century. 2. Islam and cultureIslamic countries-2Ist century. 3. Islam in mass media. 4. Popular cultureIslamic countries. I. Nieuwkerk, Karin van, I960- editor. II. LeVine, Mark, editor. III. Stokes, Martin, editor.

BPI6I.3.1727 2016

$297.2^{\prime} 7-\mathrm{dc} 23$

2015033637

doi: $10.7560 / 308875$ 